\title{
Spontaneous vegetative propagules differentiation in Bowdichia virgilioides seedlings maintained at MS basal medium
}

\author{
Marco Aurélio Boaventura Filho ${ }^{1}$, Marco Aurélio Leite ${ }^{1}$, Lelia Mc Leod', \\ Breno Régis Santos ${ }^{2}$, Plinio Rodrigues dos Santos Filho ${ }^{1 *}$ (D)
}

10.1590/0034-737X202168010007

\begin{abstract}
Bowdichia virgilioides Kunth is a medium size tree used in folk medicine and in furniture manufacturing which makes it a target of extractive processes. The aim of this work was to evaluate the endogenous content of polymines, amino acids, and sugars in seedlings of Bowdichia virgilioides that presented or not the development of spontaneously differentiated vegetative propagules in their roots. An average of thirty percent Bowdichia virgilioides in vitro growing plants cultivated in MS basal medium without growth regulators presented the differentiation of vegetative propagules. It was noted the propagules units presents embryo-like structures (globular - to leaf-shaped features) and these plants showed a compromised development when compared to the plants that do not presented these morphogenetic structures. Total sugars and amino acids content was significantly higher in the roots of plants with the vegetative propagules. With regard to polyamines content, there was no statistical difference, for spermine and spermidine. However, higher levels of putrescine were found in plants developing vegetative propagules. In this way, these results showed that this event are related to the amino acids, sugars and polyamines, mainly putrescine content.
\end{abstract}

Keywords: sucupira preta, putrescine, plant tissue culture.

\section{INTRODUCTION}

Bowdichia virgilioides Kunth is a tree species that belongs to the Fabaceae Family. It is commonly known by sucupira-preta, sucupira-do-cerrado, sucupira-do-campo, angelim-amargoso e coração-de-negro. It's wood has naturally high density and long durability and is widely used in ediffications and furniture manufacturing. Besides it is a pioneer plant adapted to poor and dry soils, which makes it an interesting target for reforestation processes (Arantes et al., 2015). Furthermore, Bowdichia virgilioides also has medicinal properties having been included in the first edition of the Brazilian pharmacopoeia (Albuquerque et al., 2007). So it is important to implement conservation strategies for this species. In this sense, vegetative propagation is one of the most important tools for plant conservation. It can be used to produce plants commercially, or to carry out basic studies of genetics, biochemistry and many others (Fehér, 2015). Briefly, differentiated plant cells under certain circumstances can revert to an earlier developmental state (dedifferentiate). However, is not a simple event and understanding different factors involved in this process has been the focus of many scientific works all over world (Mahendran \& Bai, 2016; Mahdavi-Darvari et al., 2015; Salvo et al., 2014).

One of these factors is the polyamines (PAs) content, that are small aliphatic amines implicated in several physiological processes in plants such as, organogenesis, embryogenesis, leaf senescence, fruit development and ripening and response to abiotic and biotic stresses (Ashraf et al., 2011; Alcázar \& Tiburcio, 2014). The PAs

Submitted on November 27 th 2018 and accepted on September $4^{\text {th }}, 2020$.

${ }^{1}$ Universidade Federal de Alfenas, Departamento de Bioquímica, Alfenas, Minas Gerais, Brazil. marcao_biotech@yahoo.com.br; marco.aurelioleite@hotmail.com.br; mcleodleila@gmail.com; pliniosant@hotmail.com

${ }^{2}$ Universidade Federal de Alfenas, Instituto de Ciências da Natureza, Alfenas, Minas Gerais, Brazil. sbrenoregis@gmail.com

*Corresponding author: pliniosant@hotmail.com 
metabolism is intrinsically connected with the nitrogen metabolism especially those related to the biosynthesis of amino acids. Therefore, many scientific studies have demonstrated the role of polyamines in the initiation and/ or development of plants morphogenetic strucutres (Cheng et al., 2015; Reis et al., 2015; Vondráková et al., 2014). The aim of this work was to evaluate the endogenous content of polyamines, amino acids, and sugars in seedlings of Bowdichia virgilioides growing in MS basal medium without growth regulators that presented or not the development of spontaneous differentiated vegetative propagules in their roots.

To our knowledge, this is the first study to demonstrate the occurrence of spontaneous vegetative propagules differentiation in Bowdichia virgilioides and and its relation with biochemical parameters.

\section{MATERIALAND METHODS}

\section{Plant material, growth conditions and experimental design}

Seeds of Bowdichia virgilioides were collected between the months of november and february in four diferent locations as follows: First location, 1946'55" S and $45^{\circ} 15^{\prime} 38^{\prime \prime} \mathrm{W}$; second location, $19^{\circ} 45^{\prime} 02^{\prime \prime} \mathrm{S}$ and 4514'09"; third location, $21^{\circ} 06^{\prime} 42^{\prime \prime} \mathrm{S}$ and 45 $34^{\prime} 18^{\prime \prime} \mathrm{W}$; fourth location $26^{\circ} 46^{\prime} 40^{\prime \prime} \mathrm{S}$ and $45^{\circ} 18^{\prime} 32^{\prime \prime}$.

To break the dormancy, in the moment of use, the seeds were submerged in concentrated sulfuric acid for $10 \mathrm{~min}$. Subsequently they were washed tree times with destiled and autoclaved water, disinfested with sodium hypochlorite $2.5 \%$ for $5 \mathrm{~min}$ and washed again. Then, the seeds were inoculated in culture flasks containing $20 \mathrm{~mL}$ of MS medium (Murashige \& Skoog, 1962). The $\mathrm{pH}$ was adjusted to $5.8 \pm 0.1$ before autoclaving, which was carried out at $121{ }^{\circ} \mathrm{C}$, pressure of $1.0 \mathrm{~atm}$ for a period of $20 \mathrm{~min}$ The flasks were were kept at $25 \pm 1{ }^{\circ} \mathrm{C}$, photoperiod of 12 $\mathrm{h}$ and irradiance of $36 \mu \mathrm{mol} . \mathrm{m}^{2} . \mathrm{s}^{-1}$. There were inoculated 800 seeds, being 200 seeds for each colection point as mentioned above. The plants were randomly distributed in the growth chambre and remained in this condition for 11 months (pre-established period for the development of vegetative propagules) without changes in the culture medium. At the end of this period, it was evaluated de number of plants with spontaneous vegetative propagules differentiation. For biochemical analysis were colected four roots of each location point of plants with vegetative propagules differentiation and four roots of plants without vegetative propagules differentiation.

\section{Extraction and analysis of amino acids and sugars}

Frozen tissue samples $(200 \mathrm{mg}$ ) were ground in $2 \mathrm{~mL}$ of na MCW solution (methanol:chloroform:water, 12:5:3 $\mathrm{v}: \mathrm{v}: \mathrm{v})$ and incubated at room temperature for $24 \mathrm{~h}$. After this period, the samples were centrifuged for $30 \mathrm{~min}$ at $1500 \mathrm{~g}$, and the supernatant was mixed with chloroform and water ( $4: 1: 1.5 \mathrm{v}: \mathrm{v}: \mathrm{v})$. The aqueous phase was collected after $24 \mathrm{~h}$ and used for the analysis of amino acids and sugars.

Total soluble sugars were determined colorimetrically after reaction with anthrone (Yemm \& Willis, 1954). Briefly, samples were mixed with water in a final volume of $1 \mathrm{~mL}$ and mixed with $2 \mathrm{~mL}$ of anthrone reagent (20 mg anthrone, $500 \mu \mathrm{l}$ water and $10 \mathrm{~mL}$ concentrated $\mathrm{H}_{2} \mathrm{SO}_{4}$ ). The samples were shaken and subsequently heated at $100{ }^{\circ} \mathrm{C}$ for $5 \mathrm{~min}$. Absorbance was determined at $620 \mathrm{~nm}$ and quantification based on standard curve of glucose.

Total amino acid content was determined according to Yemm \& Cocking (1955). Aliquots of the extracts were added to distilled water in a final volume of $1 \mathrm{~mL}$. Subsequently, $1.7 \mathrm{~mL}$ of the following reagents were added: $0.2 \mathrm{M}$ sodium citrate buffer $\mathrm{pH} 5(0.5 \mathrm{~mL}), 5 \%$ methanol solubility in water $(0.2 \mathrm{~mL})$ and $2 \% \mathrm{KCN}$ in methylcellose $(1 \mathrm{~mL})$. This mixture was stirred and heated at $100^{\circ} \mathrm{C}$ for 20 min. After cooling at room temperature, $1.3 \mathrm{~mL}$ of $60 \%$ ethanol was added to the samples and the absorbance at $570 \mathrm{~nm}$ was determined. Quantification was performed based on standard curve of glutamine.

\section{Free polyamines determination}

Frozen samples $(500 \mathrm{mg}$ ) were macerated in $3 \mathrm{~mL}$ of $5 \%$ perchloric acid (v/v) and keeped at $4{ }^{\circ} \mathrm{C}$ for $1 \mathrm{~h}$. After that, the samples were centrifuged at $15000 \mathrm{~g}$ for $20 \mathrm{~min}$ at $4{ }^{\circ} \mathrm{C}$. The supernatant containing the free polyamines was removed and the pellets were re-extracted. The supernatants were combined and the pellets were eliminated. Free polyamines were derivatized by dansyl chloride diluted in acetone at the concentration of 5 $\mathrm{mg} \cdot \mathrm{mL}^{-1}$. An aliquot of $40 \mu \mathrm{l}$ of the samples were added to $100 \mu \mathrm{l}$ of dansyl chloride and $50 \mu \mathrm{l}$ of saturated sodium carbonate. This mixture were incubated in the dark for 50 $\min$ at $70^{\circ} \mathrm{C}$.

After that, the excess of dansyl chloride was converted to densyl proline by the addition of $25 \mu \mathrm{l}$ of proline (100 $\mathrm{mg} \mathrm{m} \mathrm{m}^{-1}$ ). After $30 \mathrm{~min}$ incubation the dansylated polyamines were extracted by the addition of $200 \mu \mathrm{l}$ of toluene. The toluene phase was collected and dried in nitrogen and the dansylated polyamines were solubilized in $200 \mu \mathrm{l}$ of acetonitrile. The polyamines were separated and analyzed by reverse phase HPLC using a $5 \mu \mathrm{m}, 250$ $\mathrm{mm} \times 4.60 \mathrm{~mm} \mathrm{C}-18$ column. The mobile phase was composed of absolute acetonitrile (solvent $\mathrm{A}$ ) and $10 \%$ acetonitrile in water ( $\mathrm{pH} 3.5$; solvent $\mathrm{B}$ ) in a flow rate of 1 $\mathrm{mL} / \mathrm{min}$ at $40^{\circ} \mathrm{C}$. The gradient of solvent $\mathrm{A}$ were as follows: $65 \%$ over the first $10 \mathrm{~min}, 65$ to $100 \%$ between 10 and 13 min and 100\% between 13 and 21 min. (Silveira et al., 2004). 
The concentration of the polyamines was monitored with a fluorescence detector operating at 340 and $510 \mathrm{~nm}$ of excitation and emission wavelength respectivelly. Free polyamines were derivatized by dansyl chloride diluted in acetone at the concentration of $5 \mathrm{mg} \mathrm{ml}^{-1}$. An aliquot of 40 $\mu l$ of the sample was added to $100 \mu \mathrm{l}$ of dansyl chloride, 50 $\mu l$ of saturated sodium carbonate. As standards were used the commercial compounds putrescine, spermidine and spermine.

\section{STATISTICAL ANALYSIS}

The data were submitted to analysis of variance and the means were compared by the Tukey test at $5 \%$ of significance.

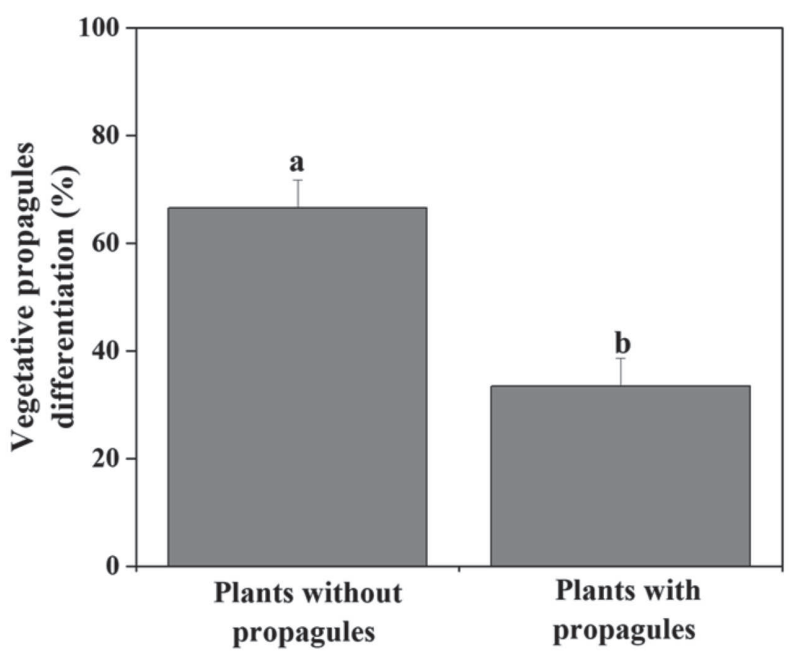

Figure 1: Percentage of in vitro Bowdichia virgilioides seedlings with or without spontaneous vegetative propagules differentiation after eleven months of in vitro cultivation. The bar represent the mean \pm SD. Different letters indicate that that the data are statistically different by the Tukey test at $5 \%$ significance level.

\section{RESULTS AND DISCUSSION}

It was observed that some plants of Bowdichia virgilioides cultivated in vitro in MS medium without supplementation of growth regulators presented after a few months the development of vegetative propagules in their roots. With this in mind, Bowdichia virgilioides seeds were inoculated and the plants were cultivated for eleven months in order to analyse the vegetative propagules formation. It is worth mentioning that the plants were randomly allocated at the growth chamber and maintained at the same conditions throughout the cultivation period. This period of cultivation was chosen because we observe in previous experiments that the propagules formation begins around the sixth month and after the eleventh month there were no emergence of new propagules units. As can be seen in the Figure 1 an average of thirty percent of the obtained plants presented the development of vegetative propagules. Besides that, was noted that these plants showed a compromised development when compared to the plants that did not present vegetative propagules (Figure $2 \mathrm{~A}$ and B). According to Vila et al. (2005), the use of roots as a source of explants for in vitro regeneration is limited to a few number of plant species. Besides that, there are several reports about the development of organogenic structures in regeneration systems from roots (Choffe et al., 2000; Da Cruz et al., 2014; Da Silva et al., 2011). However, to a better knowledge of these structures histological examinations are necessary. From this point of view Haensch (2004) presents an interesting argumentation about embryo-like structures in Pelargonium hortorum. He reports globular - to leaf-shaped structures or similar to shoots, but with vascular connections with the parent explant and the lack of bipolarity. As can be can be seen in

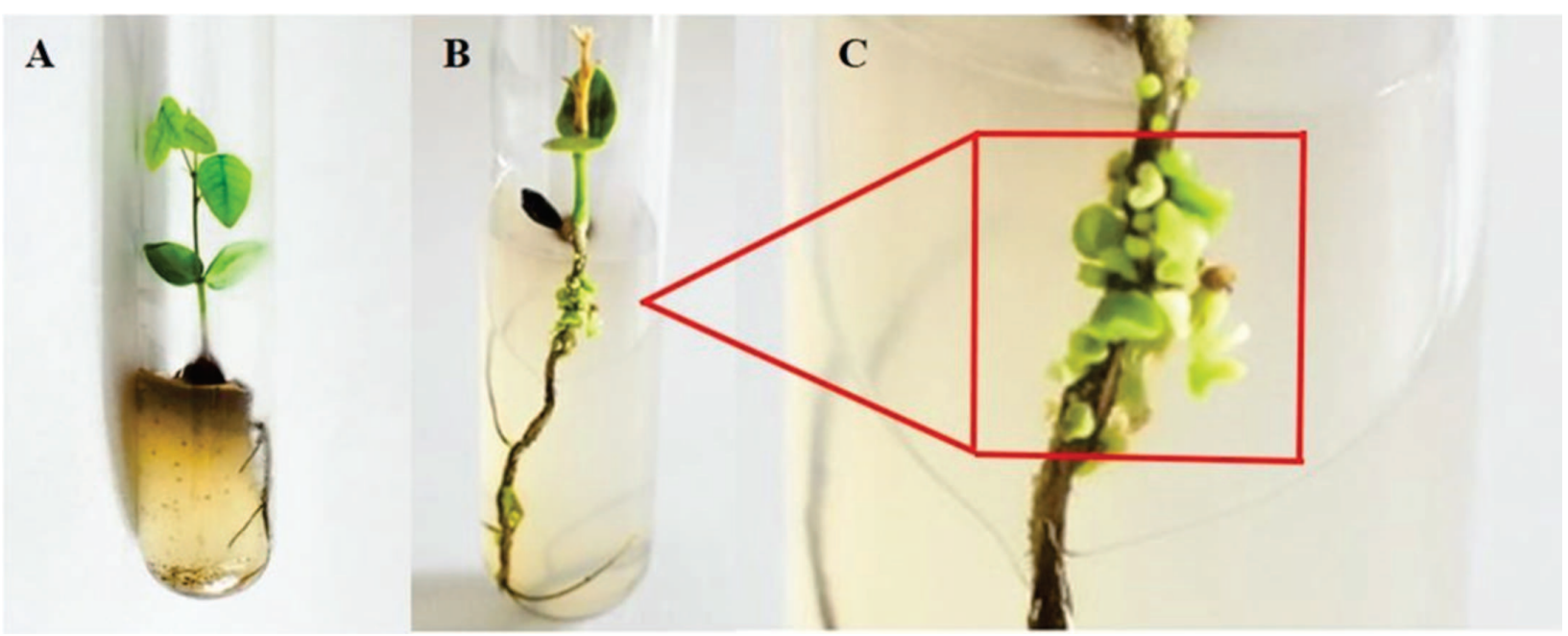

Figure 2: Samples of seedlings without (A) and with (B) spontaneous vegetative propagules differentiation and approximate detail (C) of roots developing propagules units. 
more detail in the figure $2 \mathrm{C}$, the propagules units presents globular - to leaf-shaped features. However, ultrastructural characteristics of the cells were not elucidate.

It is well known that the addition of growth regulators is an extremely relevant factor for the induction of organogenetic process in in vitro growing plants (Asthana et al., 2017; Mose et al., 2017; Roshanfekrrad et al., 2017; Shen et al., 2018, Da Cruz et al., 2014; Da Silva et al., 2011). For this, it is unusual that the propagules differentiation occured without the addition of growth regulators, However, the in vitro tissue culture conditions per se expose the plants to a signifcant stresses (Feher, 2003). Under these condtions, some plant cells presents a remarkable feature of change their fate as a stress response (Kaur et al., 2018) and the adaptations include several changes in the physiology and metabolism of the cells.

With this in mind, was carried out biochemical tests in the roots in order to point out possible biochemical diferences which could be related to the embryo emergence of the propagules units. This was thought because there is some evidences that changes in the levels of sugars, amino acids and polyamines are associated with development of morphogenetic responses in plants.

As can be seen in the figure $3 \mathrm{~A}$, the total sugars content was significantly higher $\left(62.67 \pm 6.57 \mu \mathrm{g} . \mathrm{g}^{-1}\right)$ in the roots of the plants presenting propagules units when compared to the plants without these structures (29.94 \pm $\left.5.81 \mu \mathrm{g} \cdot \mathrm{g}^{-1}\right)$. Grzyb et al. (2017) and Aragão et al. (2016) argue that the relationship between the endogenous content of sugars and the development of morphogenetic responses is not well known, but they suggest that these biomolecules also play a relevant role in cell signaling, acting as promoting agentes. In the same way, total amino acid content (Figure 3B) also presented higher content $(19.2326 \pm 5.3621)$ in the plants with progules units differentiation when compared with to the plants without these strucutres $(11.2709 \pm 3.59512)$.

With regard to free polyamine content (figure 4), there was no statistical difference between the plants, for spermine (Spm) and spermidine (Spd). However, higher levels of putrescine were found in the plants with progules units differentiation. Such higher content of putrescine content suggest a relationship with the the amino acid content, since the ornithine and arginine are the polyamines precursors. (Martin-Tanguy, 2001). Thus, we can hypothesize that the accumulation of amino acids supports the putrescine biosynthesis and these events,

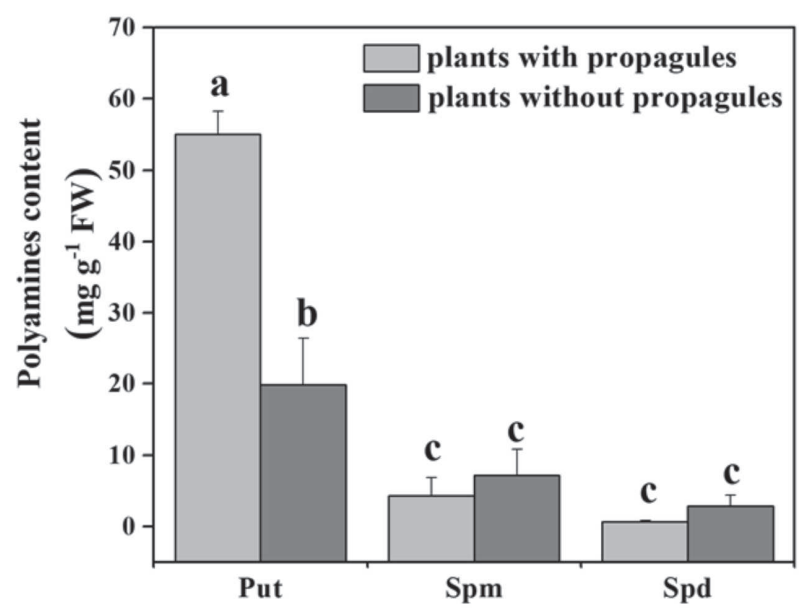

Figure 4: Free Polyamines in roots of Bowdichia virgilioides plants with and without spontaneous vegetative propagules differentiation. Put, putrescine; Spm, spermine; Spd, spermidine. The bar represent the mean \pm SD. Different letters indicate that the data are statistically different by the Tukey test at $5 \%$ significance level.
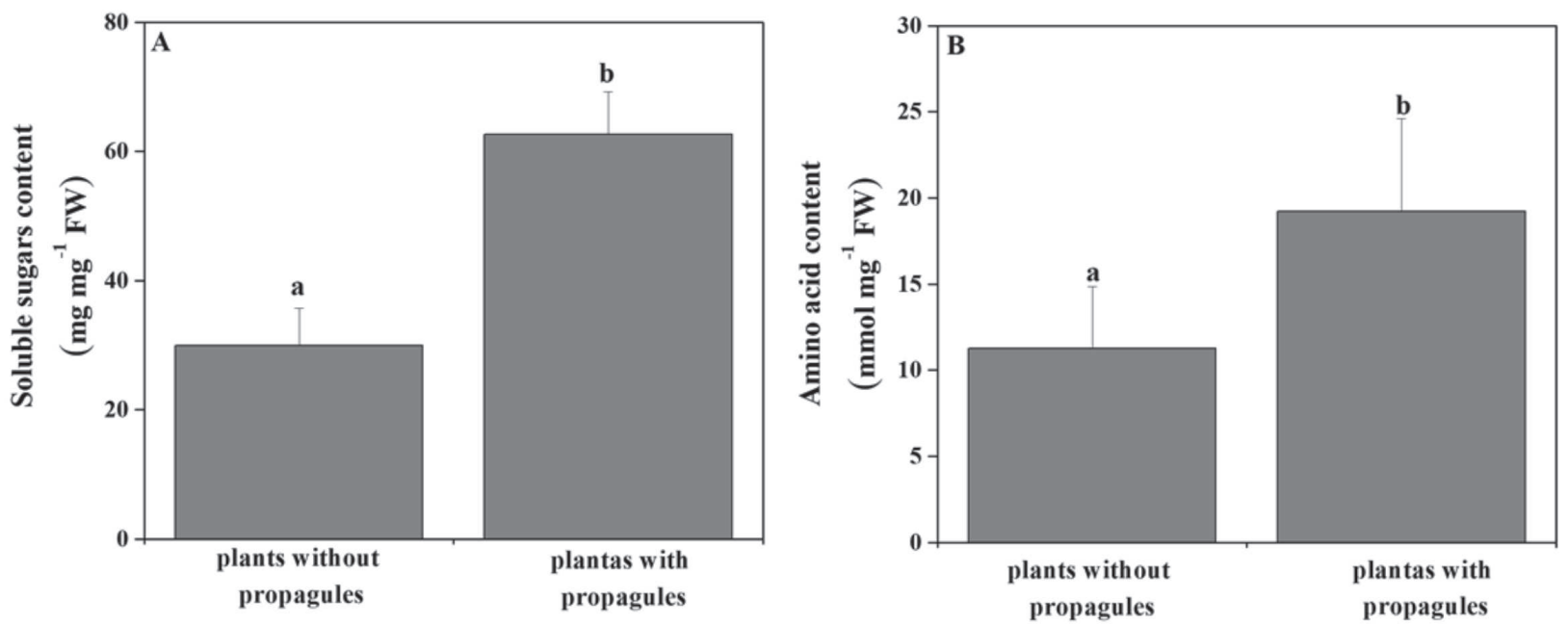

Figure 3: Total concentration of soluble sugars (A) and amino acids (B) in roots of Bowdichia virgilioides plants without and with spontaneous vegetative propagules differentiation. Bar represent the mean \pm SD. Different letters indicate that the data are statistically different by the Tukey test at 5\% significance level.

Rev. Ceres, Viçosa, v. 68, n.1, p. 055-060, jan/feb, 2021 
together, may be associated with the emergence of the vegetative propagules. The polyamines are, intrinsically associated with the morphogenetic responses as demonstrated by Reis et al. (2015) in sugarcane, which obtained the largest quantity of embryos with putrescine supplementation. Other works also supports the role of polyamines, manly putrescine, on the induction of morphogenetic responses like in vitro rooting (Matam \& Parvatam, 2017), conversion of protocorms like-bodies to shoots (Wei et al., 2010) and shoot organogenesis (Parimalan et al., 2011).

\section{CONCLUSION}

Bowdichia virgilioides in vitro growing plants cultivated in MS basal medium without growth regulators presented the differentiation of vegetative propagules in their roots;

This event are related to the amino acids, sugars and polyamines content;

The propagules units presents embryo-like structures (globular - to leaf-shaped features), however, the ultrastructural carachteristics will be determined in future works.

\section{ACKNOWLEDGEMENTS}

We would like to thanks FAPEMIG, CNPq and CAPES for the financial support. The authors further declare that there is no any conflict of interests

\section{REFERENCES}

Albuquerque KA, Guimarães RM, Almeida IF \& Clemente ADCS (2007) Métodos para superação da dormência em sementes de sucupira-preta (Bowdichia virgilioides Kunth). Ciência e Agrotecnologia, 31:1716-1721.

Alcázar R \& Tiburcio AF (2014) Plant polyamines in stress and devopment: an emerging area of research in plant sciences. Frontiers in Plant Science II, 5:319.

Aragão VPM, de Souza Ribeiro YR, Reis RS, Macedo AF, Floh EIS, Silveira V \& Santa-Catarina C (2016) In vitro organogenesis of Cedrela fissilis Vell. (Meliaceae): the involvement of endogenous polyamines and carbohydrates on shoot development. Plant Cell, Tissue and Organ Culture, 124:611-620.

Arantes CS, Do Prado Júnior JÁ, Sousa JR, Do Vale VS \& De Oliveira RMC (2015) Ação Facilitadora de Bowdichia virgilioides Kunth (Fabaceae) na Colonização de Espécies em uma Área de Cerrado Sentido Restrito. Caminhos de Geografia, 16:15-26.

Ashraf M, Akram NA, Al-Qurainy F \& Foolad MR (2011) Drought tolerance: roles of organic osmolytes, growth regulators and mineral nutrients. Advances in Agronomy, 111:249-296.

Asthana P, Rai MK \& Jaiswal U (2017) Somatic embryogenesis from sepal explants in Sapindus trifoliatus, a plant valuable in herbal soap industry. Industrial Crops and Products, 100:228235 .

Cheng WH, Wang FL, Cheng XQ, Zhu QH, Sun YQ, Zhu HG \& Sun J (2015) Polyamine and it metobolite $\mathrm{H}_{2} \mathrm{O}_{2}$ play a key role in the conversion of embriogenic callus into somatic embryos in upland cotton. Frontiers in Plant Science, 6:1063.
Choffe KL, Murch SJ \& Saxena PK (2000) Regeneration of Echinacea purpurea: induction of root organogenesis from hypocotyl and cotyledon explants. Plant Cell, Tissue and Organ Culture, 62:227-234.

Da Cruz ACF, Rocha DI, Iarema L, Ventrella MC, Costa MGC, Neto VBP \& Otoni WC (2014) In vitro organogenesis from root culture segments of Bixa orellana L. (Bixaceae). In Vitro Cellular \& Developmental Biology-Plant, 50:76-83.

Da Silva CV, de Oliveira LS, Loriato VAP, da Silva LC, de Campos JMS, Viccini LF \& Otoni WC (2011) Organogenesis from root explants of commercial populations of Passiflora edulis Sims and a wild passionfruit species, $P$. cincinnata Masters. Plant Cell, Tissue and Organ Culture (PCTOC), 107:407-416.

Fehér A (2015) Somatic embryogenesis-stress-induced remodeling of plant cell fate. Biochimica et Biophysica Acta (BBA)-Gene Regulatory Mechanisms, 1849:385-402, 2015.

Feher A, Pasternak TP \& Dudits D (2003) Transition of somatic plant cells to an embryogenic state. Plant Cell, Tissue and Organ Culture, 74:201-228.

Grzyb M, Kalandyk A, Waligórski P \& Mikuła A (2017) The content of endogenous hormones and sugars in the process of early somatic embryogenesis in the tree fern Cyathea delgadii Sternb. Plant Cell, Tissue and Organ Culture, 129:387-397.

Haensch KT (2004) Morpho-histological study of somatic embryolike structures in hypocotyl cultures of Pelargonium $\times$ hortorum Bailey. Plant Cell Reports, 22:376-381

Kaur A, Reddy MS \& Kumar A (2018) Direct somatic embryogenesis of potato [Solanum tuberosum (L.)] cultivar 'Kufri Chipsona 2'. Plant Cell, Tissue and Organ Culture, 134:457-466.

Mahdavi-darvari F, Noor NM, \& Ismanizan I (2015) Epigenetic regulation and gene markers as signals of early somatic embryogenesis. Plant Cell, Tissue and Organ Culture, 120:407422.

Mahendran G \& Bai VN (2016) Direct somatic embryogenesis of Malaxis densiflora (A. Rich.) Kuntze. Journal of Genetic Engineering and Biotechnology, 14:77-81.

Martin-Tanguy J (2001) Metabolism and function of polyamines in plants: recent development (new approaches). Plant Growth Regulation, 34:135-148.

Matam P \& Parvatam G (2017). Putrescine and polyamine inhibitors in culture medium alter in vitro rooting response of Decalepis hamiltonii Wight \& Arn. Plant Cell, Tissue and Organ Culture, 128:273-282.

Mose W, Indrianto A, Purwantoro A \& Semiarti E (2017) The Influence of Thidiazuron on Direct Somatic Embryo Formation from Various Types of Explant in Phalaenopsis amabilis (L.) Blume Orchid. HAYATI Journal of Biosciences, 24:201-205.

Murashige T \& Skoog F (1962) A revised medium for rapid growth and bioassays with tobacco tissue cultures. Physiology Plantarum, 15:473-479.

Parimalan R, Giridhar P \& Ravishankar GA (2011) Enhanced shoot organogenesis in Bixa orellana L. in the presence of putrescine and silver nitrate. Plant Cell, Tissue and Organ Culture, 105:285-290.

Reis RS, Vale EM, Heringer AS, Santa-Catarina C \& Silveira V (2015) Putrescine induces somatic embryo development and proteomic changes in embryogenic callus of sugarcane. Journal of Proteomics, 130:170-179.

Roshanfekrrad M, Zarghami R, Hassani H, Zakizadeh H \& Salari A (2017) Effect of $\mathrm{AgNO}_{3}$ and BAP on root as a novel explant in date palm (Phoenix dactylifera cv. Medjool) somatic embryogenesis. Pakistan Journal of Biological Sciences, 20:20-27. 
Salvo AS, Hirsch CN, Buell CR, Kaeppler SM \& Kaeppler HF (2014) Whole transcriptome profiling of maize during early somatic embryogenesis reveals altered expression of stress factors and embryogenesis-related genes. PLoS One, 9:e111407.

Shen HJ, Chen JT, Chung HH \& Chang WC (2018) Plant regeneration via direct somatic embryogenesis from leaf explants of Tolumnia Louise Elmore 'Elsa'. Botanical Studies, $59: 4$.

Silveira V, Floh EIS, Handro W \& Guerra MP (2004) Effect of plant growth regulators on the cellular growth and levels of intracellular protein, starch and polyamines in embryogenic suspension cultures of Pinus taeda. Plant Cell, Tissue and Organ Culture, 76:53-60.

Vila S, Gonzalez A, Rey H \& Mroginski L (2005) Plant regeneration, origin, and development of shoot buds from root segments of Melia azedarach L. (Meliaceae) seedlings. In Vitro Cellular \& Developmental Biology-Plant, 41:746.
Vondráková Z, Eliásová K, Vágner M, Martincová O \& Cvikrova M (2015) Exogenous putrescine affects endogenous polyamine levels and the development of Picea abies somatic embryos. Plant Growth Regulation, 75:405-414.

Wei M, Wei SH \& Yang CY (2010) Effect of putrescine on the conversion of protocorm-like bodies of Dendrobium officinale to shoots. Plant Cell, Tissue and Organ Culture, 102:145-151.

Yemm EW \& Cocking EC (1955) The determination of aminoacids with ninhydrin. Analyst, 80:209-213.

Yemm EW \& Willis AJ (1954) The estimation of carbohydrates in plant extracts by anthrone. Biochemical Journal, 57:508514 